BNL- -43602

DE90 005185

\title{
FRACTOGRAPHY EVALUATION OF IMPACT AND TENSILE SPECIMENS FROM THE HFBR
}

\author{
C. J. Czajkowski
}

DISCLAIMER

\begin{abstract}
This report was prepared as an account of work sponsored by an agency of the United States Government. Neither the United States Government nor any agency thereof, nor any of their employees, makes any warranty, express or implied, or assumes any legal liability or responsibility for the accuracy, completeness, or usefulness of any information, apparatus, product, or process disclosed, or represents that its use would not infringe privately owned rights. Reference herein to any specific commercial product. process, or service by trade name, trademark, manufacturer, or otherwise does not necessarily constitute or imply its endorsement, recommendation, or favoring by the United States Government or any agency thereof. The views and opinions of authors expressed herein do not necessarly state or reflect those of the United States Government or any agency thereof.
\end{abstract}

October 1989

\section{PREPARED FOR THE BROOKHAVEN NATIONAL LABORATORY HIGH FLUX BEAM REACTOR DIVISION \\ CONTRACT NO. DE-AC02-76CH00016}




\section{DISCLAIMER}

This report was prepared as an account of work sponsored by an agency of the United States Government. Neither the United States Government nor any agency thereof, nor any of their employees, nor any of their contractors, subcontractors, or their employees, makes any warranty, expressed or implied, or assumes any legal liability or responsibility for the accuracy, completeness, or usefulness of any information, apparatus, product, or process disclosed, or represents that its use would noi infringe privately owned rights. Reference herein to any specific commercial product, process, or service by trade name, trademark, manufacturer, or otherwise, does not necessarily constitute or impiy its endorsement, recomendation, or favoring by the United States Government or any agency thereof. The views and opinions of authors expressed herein do not necessarily state or reflect those of the United States Government or any agency or subcontract thereof.

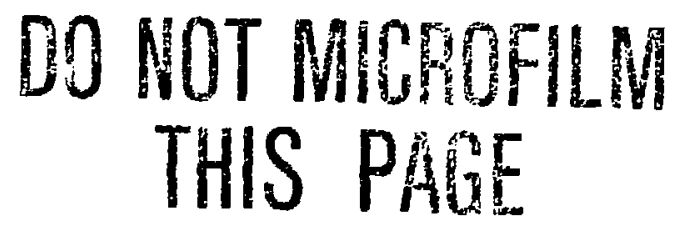


FRACTOGRAPHY EVALUATION OF IMPACT AND TENSILE SPECIMENS FROM THE HFBR

\author{
C. J. Czajkowski
}

October 1989

Nuclear Waste and Materials Technology Division Department of Nuclear Energy, Brookhaven National Laborator:" Upton, New York 11973

*This work was performed under the auspices of the U.S. Department of Energy. 


\section{ABSTRACT}

The Materials Technology Group of the Department of Nuclear Energy (DNE) at Brookhaven National Laboratory (BNL) has performed a fractographic examination of neutron irradiated and unirradiated tensile and Charpy "V" notch specimens. The evaluation was carried out using a scanning electron microscope (SEM) to evaluate the fracture mode. Photomicrographs were then evaluated to determine the extent of ductility present on the fracture surfaces of the unirradiated specimens. Ductility area measurements ranged from $4.6-9.5 \%$ on typical photomicrographs examined. 
TABLE OF CONTENTS

PAGE

ABSTRACT. . . . . . . . . . . . . . .

LIST OF FIGURES .

vii

DEF INITIONS

1. INTRODUCTION.

2. EXAMINATION

3. CONCLUSION. 


\section{LIST OF FIGURES}

PAGE

FIGURE 1

Fractograph of unirradiated 6061 T-6

tensile specimen. ............

FIGURE la

The as measured ductility of this area measured $95.4 \%$ (typical).

FIGURE 2

Low magnification fractograph of an

unirradiated tensile specimen (4032 alloy). . .

FIGURE 2a

Higher magnification photo showing essentially

$100 \%$ ductility on fracture surface. . . . .

FIGURE 3

Low magnification fractograph of an

irradiated tensile specimen from the HFBR . . . .

FIGURE 3a

Higher magnification photograph (typical)

depicting approximately $7.4 \%$ ductility

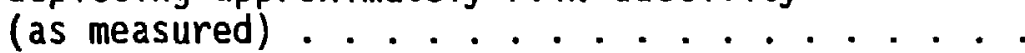

FIGURE 4

Fractograph of Charpy " $V$ " notch specimen from a 4032 alloy tested at room temperature

(9.75 inch-1bf) ..........

FIGURE $4 a$

Fractograph of area near the notch. Totally ductile fracture (typical).........

FIGURE $4 b$

The side opposite the notch of the specimen

was al so purely ductile (typical) .......

FIGURE 5

Fractograph of Charpy " $V$ " notch specimen from

a 4032 alloy tested at $210^{\circ} \mathrm{F}$ (12 inch-1bf). . .

FIGURE $5 a$

Essentially pure ductile failure was seen at higher magnification near the notch (typical) . .

FIGURE $5 b$

The same mode of failure was seen on the opposite side of the fracture (typical) .... .

FIGURE 6

Low magnification SEM photograph of the

fracture from a 6061 T-6 alloy impact tested

at $210^{\circ} \mathrm{F}(18.75$ inch-1bf $) \ldots . . .$.

FIGURE 7

Fractograph of impact specimen tested at room temperature 6061 T-6 (21.75 inch-1bf).

FIGURE 8

Low magnification SEM photograph of irradiated

HFBR impact specimen (outside high flux area).

Testing was accomplished at room temperature. 
FIGURE $8 \mathrm{a}$

FIGURE $8 b$

FIGUR: 9

FIGURE 9a

FIGURE $9 b$

FIGURE 10

FIGURE 10a

FIGURE 10b

FIGURE 11

FIGURE 11a

FIGURE $11 \mathrm{~b}$

FIGURE 12

FIGURE $12 \mathrm{a}$

FIGURE $12 b$

The measured ductility area of the

specimen near the notch was $8.7 \%$ (typical). . .

The ductility measured on the opposite side of the specimen was $8.1 \%$ (typical). . . . . .

Fractograph of irradiated impact specimen C-1

(HFBR). The specimen was tested at room

temperature $(3.0$ inch-1bf). .......

The ductility area measured $5.3 \%$ (typical)

near the notch. .............

The opposite side of the specimen had a measured area ductility of $4.6 \%$.......

HFBR follower specimen (impact) C-8 tested at room temperature (2.75 inch-1bf) ......

The area near the notch (typical) exhibited a measured ductility area of $5.3 \%$......

The opposite side of the fracture face had an area of $5.4 \%$ ductility. . . . . . . .

HFBR follower specimen (impact tested at $\left.210^{\circ} \mathrm{F}\right) \mathrm{C}-4$ had an absorbed impact energy of

2.0 inch-lbf.

The fracture face of $\mathrm{C}-4$ near the notch showed a ductility area of $9.5 \%$.......

The ductility area on the opposite sice of the fracture face measured $8.4 \%$. . . . . . .

Another HFBR specimen ( $C-5$ ) impact tested at $210^{\circ} \mathrm{F}$ had an absorbed impact energy of

3.25 inch-1bf . . . . . . . . . .

A ductility measurement of $6.3 \%$ was obtained near the notch ..........

A ductility area of $6.8 \%$ (typical) was seen near the opposite side of the fracture. . . . . 


\section{DEFINITIONS}

Fracture normally occurs in two stages:
a) Nucleation of the crack
b) Propagation of the crack

Fractographically, fractures can be either intergranular or transgranular in appearance. Intergranular cracking occurs in grain boundaries while transgranular cracking follows a path through the grains.

Most service/test failures cracks display a combination of various fracture modes which for the case of this examination would include:

a) Microvoid coalescence/dimple rupture:

In metallic materials which fracture under single load or by tearing, the fracture surfaces show numerous depressions in microstructures. These surface features are known as dimples in fracture terminology and, hence, the name dimple rupture is given to this type of fracture mode. Dimples form by a process of microvoid nucleation on or around sites where local plastic deformation is high. Microscopic inhomogeneities like precipitates, inclusions, grain boundaries, etc., act as preferred sites for microvoid nucleation. Under increasing strain, microvoids grow, coalesce, and eventually rupture to produce dimples on the fractured surfaces.

b) Transgranular cleavage:

This fracture exhibits little or no plastic deformation and occurs along low-index, well-defined crystallographic planes. This type of fracture is 
common in bcc and hcp materials. In fcc materials, the cleavage mode is restricted to external conditions, e.g., cracking of aluminum alloys in the presence of mercury, stress-corrosion cracking of brass, and corrosion fatigue in some alloys.

Cleavage mode of fracture is favored under high triaxial stress (at the root of a notch), at high deformation rates (impact testing) and low temperature conditions.

c) decohesive rupture:

Separation of fracture surfaces along weak fracture paths is known as decohesive rupture. Two main factors that can promote this mode of fracture are: (1) morphological variables such as copious grain-boundary precipitation and formation of low-strength phases and defect structures along grain boundaries; (2) environmental factors which promote environment-material interaction such as stress-corrosion cracking and hydrogen embrittlement, which, in turn, leads to ultimate failure under applied load.

The above definitions for these three fracture modes were taken from the IITRI Fracture Handbook, "Failure Analysis of Metallic Materials By Scanning Electron Microscopy," Chicago, January 1979. 


\section{INTRODUCTION}

In October 1988, the Reactor Division (RD) of Brookhaven National Laboratory contracted with the Materials Technology Group of the Department of Nuclear Energy (DNE) to machine and test specimens from an HFBR control rod follower.

The purpose of the program was twofold:

a) Four tensile specimens were required to be machined and tested (HFBR Technical Specification Requirement).

b) The Shewmon committee had requested BNL to perform evaluations of the fracture toughness of the HFBR beam tube materials. After extended discussions with the Structural Analysis Division of DNE, it was decided that Charpy impact specimens would be machined and tested.

Charpy impact specimens were chosen because they could be reproducibly machined and tested in the BNL Metallurgical Hot Cell with the equipment and personnel available at the time of program inception.

The results of these tests were presented to the RD in a report in August 1989.

On July 18, 1989, an HFBR review committee evaluated the materials work performed and provided the following guidance in their summary and recommendations:

"We believe that cracks can open up in the beam tubes of the HFBR reactor only if, and when, they are exposed to tensile stresses, or large shear stresses. These might be large transient stresses, or. continued exposure to smaller tensile stresses. A detailed stress analysis has shown that the external pressure on the beam tubes maintain compressive stresses in all regions of the body of the beam 
tubes (but not in the tips of the cooling fins) during normal operation. Tensile stresses can only develop in the body of the beam tubes when there are depressurization transients. Even then the maximum credible tensile stresses are quite low, and the maximum stress intensity that could develop beneath a long crack which lay in the worst location and penetrated $60 \%$ of the way through the wall thickness is low (<1000 psi/in).

Measurements of the toughness of the irradiated beam tube material indicate that while expusure to the high neutron flux has significantly reduced its toughness, the ramaining bughinss is sti: estimated to be a factor of 7 above this level of $1000 \mathrm{psi} / \mathrm{in}$.

Based on the available evidence we would expect that the beam tubes do not constitute an undue safety risk for the continued operation of the HFBR. Analysis shows that telisile stresses are found only under upset conditions and fracture at the upset stress levels if the tubes are badly flawed. However, we believe the following tests should be carried out to better establish the safety margin against brittle fracture:

1. Because the toughness test results that have been completed give only approximate values, we recommend the following tests should be carried out, one immediately, and the other in the future:

a. A fractographic examination of the fracture surface of the notched impact specimens (the so-called Charpy specimens) should be performed to estimate the amount of plastic deformation required for propagation of the crack. This test should proceed immediately. If there is evidence of ductility then there is sufficient margin for safe operation. If there is no evidence of ductility, then the test described in b), below, should be done before restart. 
b. Test should be performed to more quanitatively characterize the fracture resistance (fracture toughness) of the irradiated material. This could be done by pulling side-notched samples cut from the irradiated control rod follower, as discussed with the BNL staff. If the fractographic examination indicates plastic deformation, ichese tests should be completed within the next year..."

This report is the documented results of the aforementioned fractographic analysis.

\section{EXAMINATION}

From the previously mentioned test program, various tensile and Charpy "V" notch specimens had their fracture faces removed and mounted for examination by scanning electron microscopy.

Tensile specimens were examined from unirradiated 6061 T-6 and 4032 aluminum alloys and one specimen from an irradiated 6061 T-6 tensile specimen (T-3) with a measured tensile strength of $100.6 \mathrm{ksi}$.

Charpy impact fracture faces were evaluated from unirradiated 6061 T-6 and 4032 alloys tested at both room temperature and $210^{\circ} \mathrm{F}$. Five irradiated 6061 T-6 Charpy impact specimens were also evaluated. From this number, three were from material previousiy tested at room temperature and two specimens previously tested at $210^{\circ} \mathrm{F}$.

Fracture faces from each of these specimens were examined by scanning electron microscopy techniques and then typical photomicrographs were taken of two representative areas on each irradiated specimen. Note: Since some of the irradiated specimens exceeded $20 \mathrm{R} / \mathrm{hr} \beta-\gamma$ at contact, only two representative (typical) photos were shot at higher magnifications to keep operator dose to a minimum. 
After all of the photographs were shot, an overlay grid was prepared. The grid sizing corresponded to 0.200 in. $\times 0.200$ in. squares copied onto a clear mylar overlay. This overlay was then used in an attempt to quantify the amount of ductility present on the fracture faces.

NOTE: While examining the photomicrographs, the most conservative approach was taken in determining ductile areas. Only areas on a plane essentially perpendicular to the electron beam were counted as ductile. Additionally, these areas were only counted as ductile if they exhibited a dimpled rupture appearance. This method yielded the lowest area ductility measurements (most conservative). The method of quantifying the amount of ductility should be viewed as more of a qualitative examination due to the conservative approach taken in examining the fracture faces.

Figures 1 - 2a are SEM fractographs of 6061 T-6 (unirradiated) tensile specimen (Figures 1 and $l a$ ) and an aluminum alloy 4032 tensile fracture (Figures 2 and 2a). The overlay was applied to both of the higher magnification photographs (approximately 400X) which resulted in measured $95.4 \%$ and essentially $100 \%$ areas of ductility present on the fractures.

Figures 3 and $3 a$ are SEM photographs of HFBR irradiated tensile specimen T-3. This fracture had a measured ductility area of $7.4 \%$.

Unirradiated fracture faces were also examined on 6061 T-6 and 4032 aluminum alloy Charpy "V" notch specimens. These specimens were tested either at room temperature (Figures $4,4 a, 4 b$ and 7 ) or at $210^{\circ} \mathrm{F}$ (Figures $5,5 a, 5 b$ and 6). In all cases the fractures showed essentially totally ductile fractures.

The first irradiated specimen examined (Figure 8) came from an area outside the area of highest fluence. The fractures of all of the irradiated impact samples had a predominantly cleavage appearance with some ductility present. This sample had values of $8.7 \%$ (Figure $8 a$ ) and $8.1 \%$ (Figure $8 b$ ) obtained with the overlay. 
Figures 9 - 10b correspond to SEM photographs of fracture surfaces from two irradiated HFBR impact specimens $(\mathrm{C}-1$ and $\mathrm{C}-8)$. The measured ductility areas (typical) for $\mathrm{C}-1$ were $5.3 \%$ (Figure $9 a$ ) and $4.6 \%$ (Figure $9 b$ ).

The measured ductility areas for specimen C-8 were $5.3 \%$ (Figure 10a) and $5.4 \%$ (Figure 10b).

The last two specimens examined were irradiated impact specimens (Figures 11 - $12 \mathrm{~b}$ ) tested at $210^{\circ} \mathrm{F}$. Specimen $\mathrm{C}-4$ had ductility measurements of $9.5 \%$ (Figure 11a) and $8.4 \%$ (Figure $11 \mathrm{~b}$ ) which were the highest values obtained. It is interesting to note that this specimen exhibited the lowest impact value (energy absorbed), 2 inch-lbf.

Figures $12-12 \mathrm{~b}$ are fractographs of impact sample C-5. Ductility areas equalling $6.3 \%$ ( $F$ igure $12 a$ ) and $6.8 \%$ (Figure $12 b$ ) were seen on the se specimens.

A caution should be offered at this juncture insofar as the measurements made during this study are of discrete areas of ductility seen on the photomicrographs. This cannot be directly related to the actual ductility of a material which one would obtain by performing a uniaxial tensile test.

\section{CONCLUSION}

The above evaluations and measurements have led to the following conclusions:

a) There are discrete areas of ductility present on the fracture surfaces of the irradiated control rod follower specimens. The quantification of the amount of ductility in evidence on the photomicrographs ranged in value from $4.6-9.5 \%$ for specimens in the highest fluence area.

b) The appearance of ductile areas on the various irradiated fracture faces examined supports the BNL position that the HFBR beam tube materials have adequate toughness for continued operation of the reactor. 


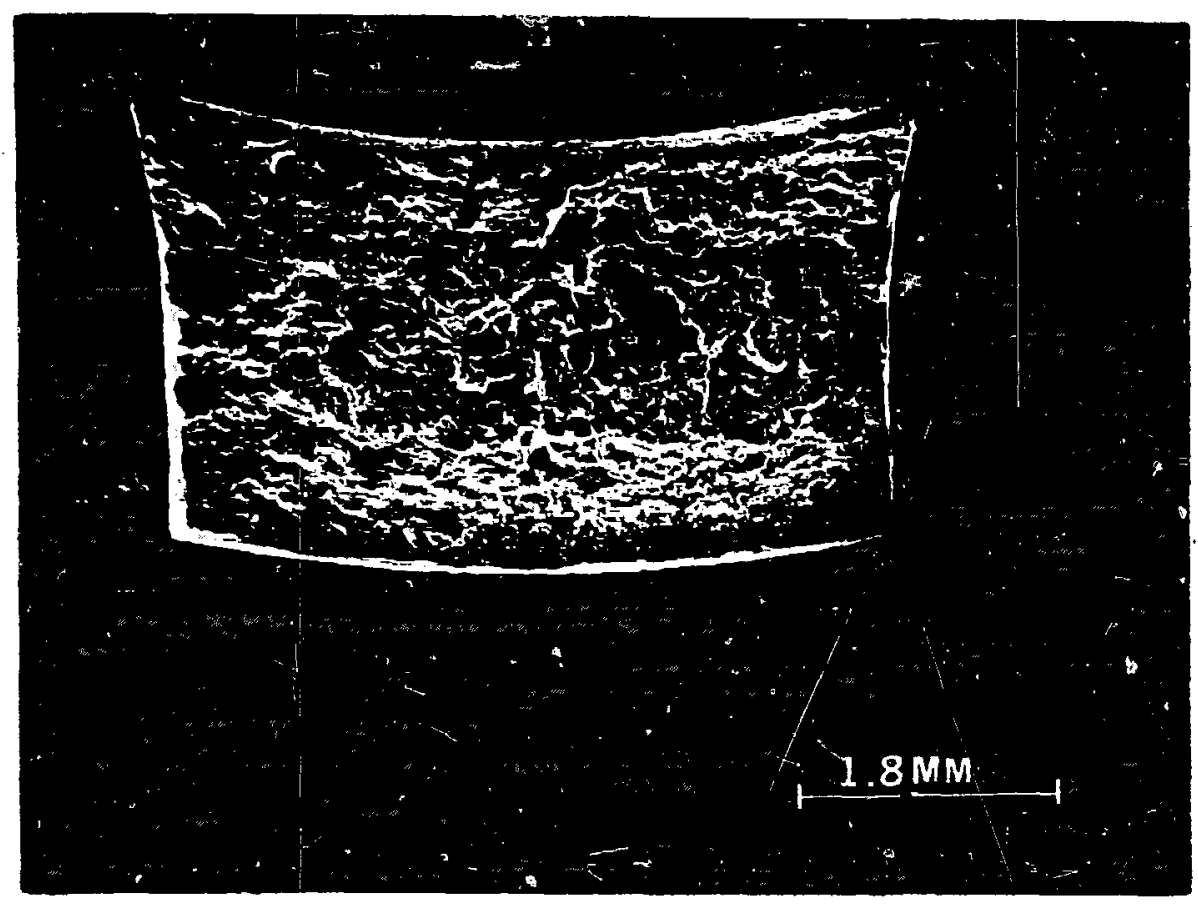

Figure 1 Fractograph of unirradiated 6061 T-6 tensile specimen.

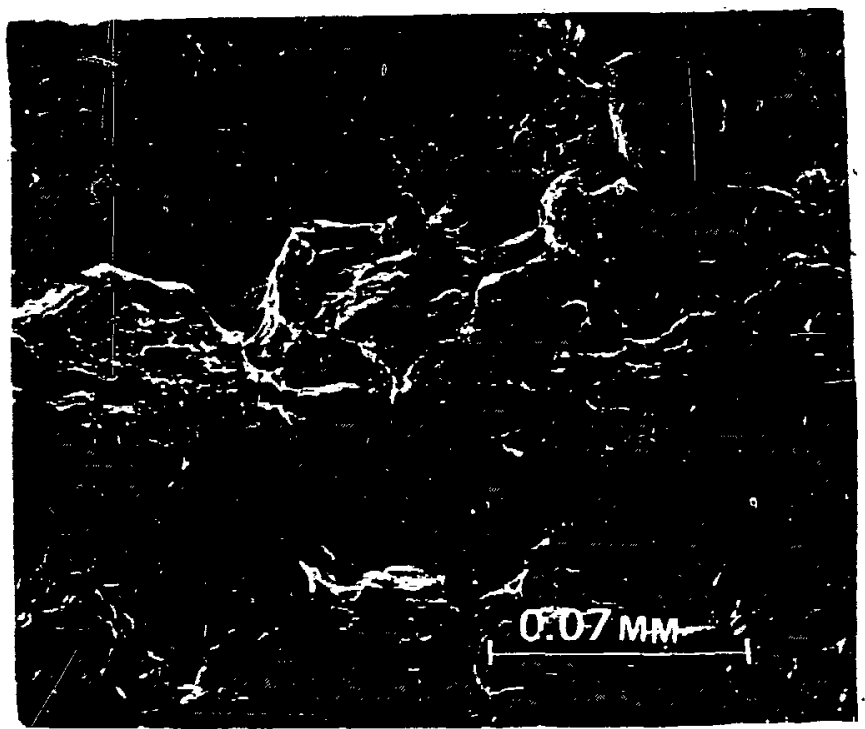

Figure la The as measured ductility of this area measured $95.4 \%$ (typica1). 


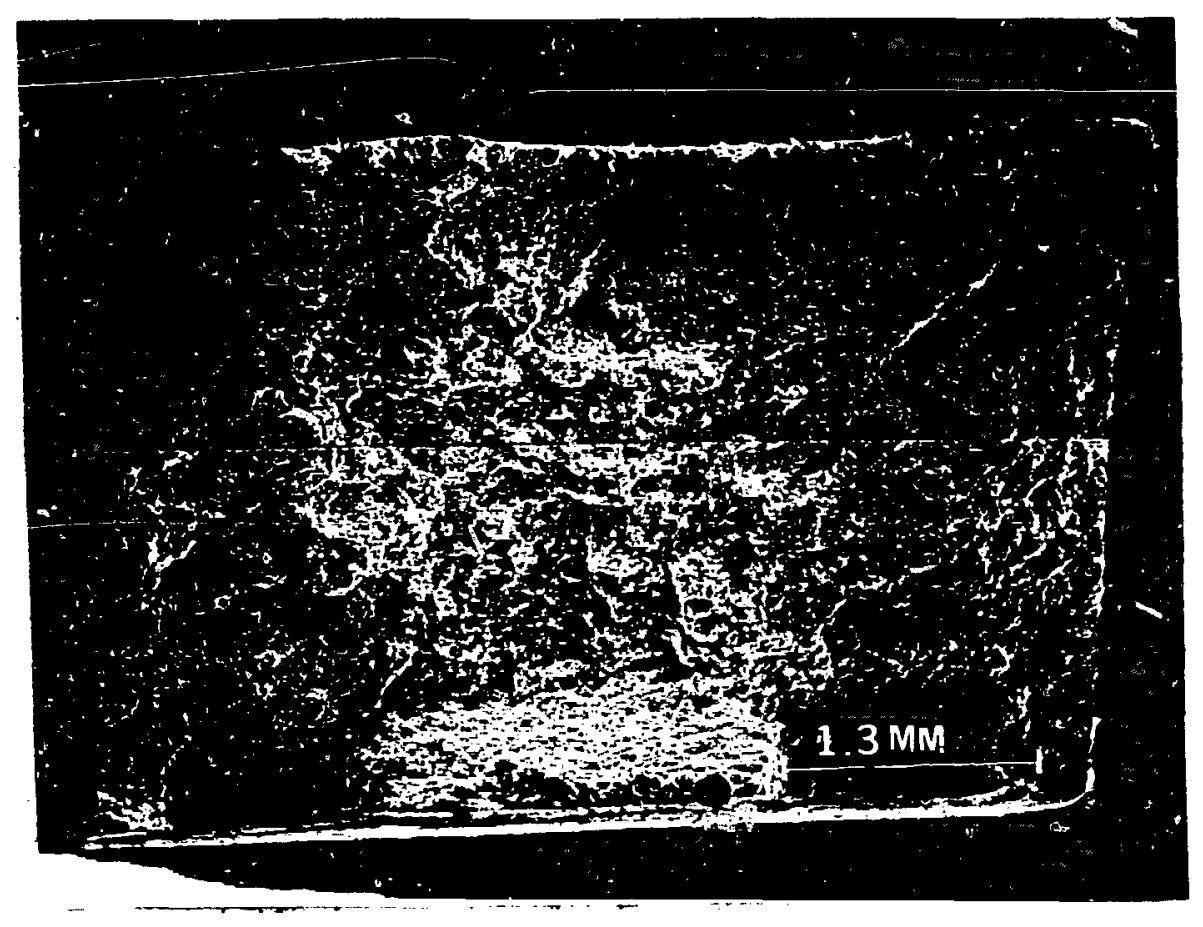

Figure 2 Low magnification fractograph of an unirradiated tensile specionen (4032 alloy).

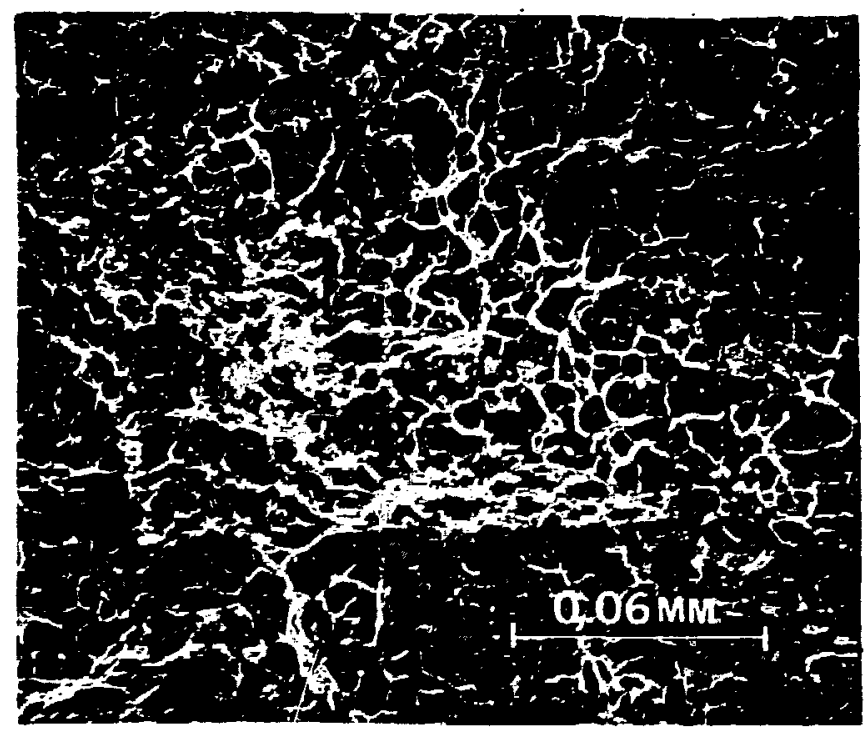

Figure $2 a$ Higher magnification photo showing essentially $100 \%$ ductility on fracture surface. 


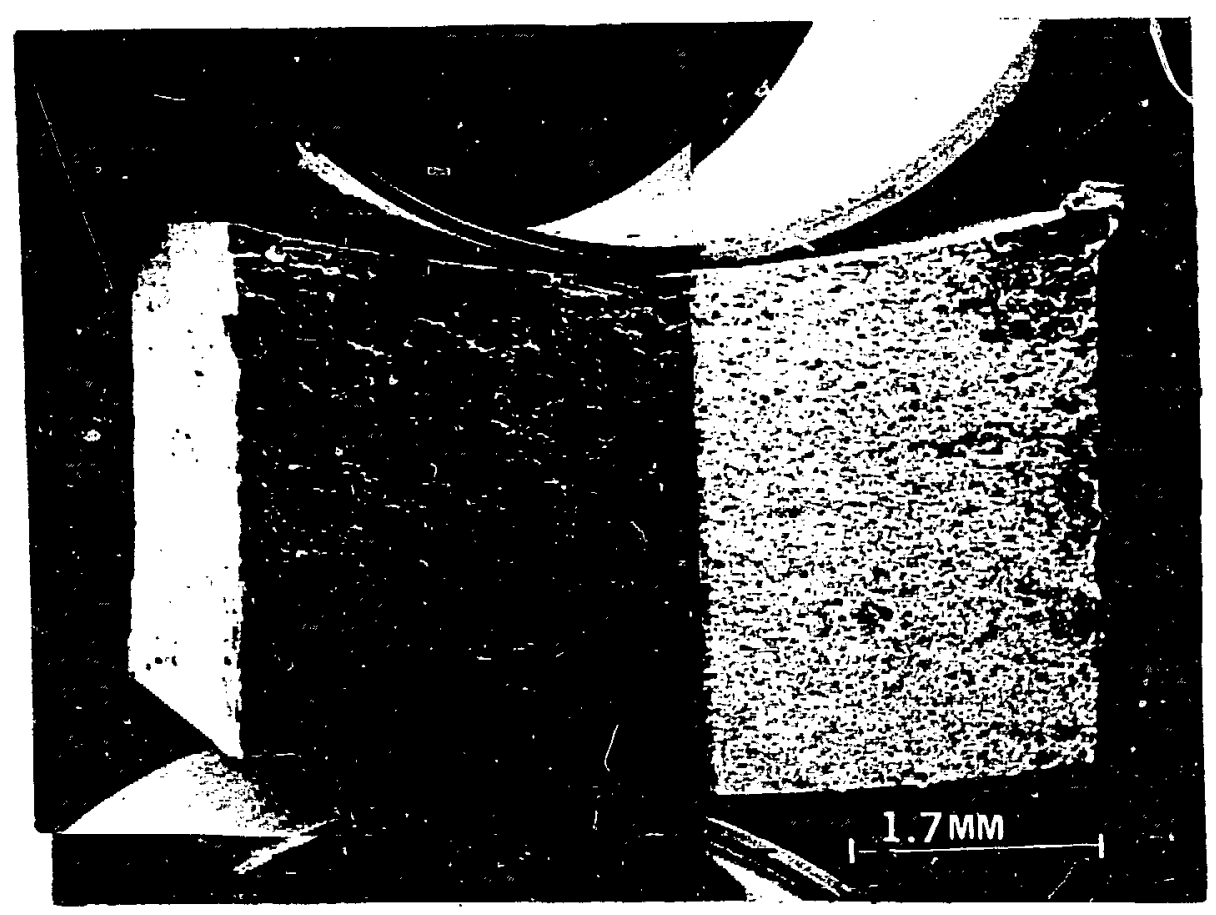

Figure 3 Low magnification fractograph of an irradiated tensile specimen from the HFBR.

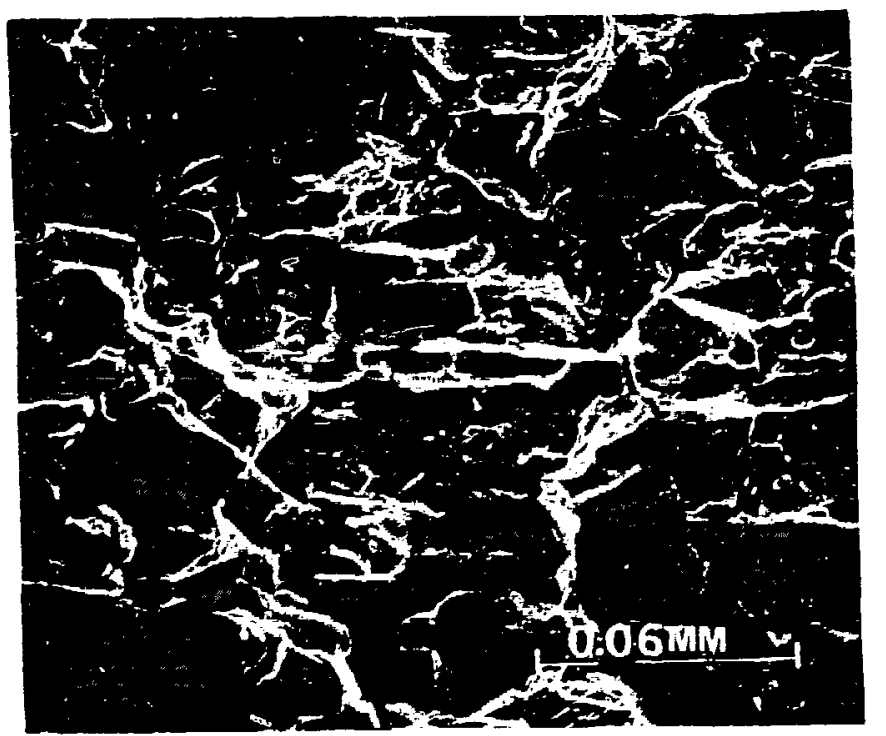

Figure 3a Higher magnification photograph (typical) depicting approximately $7.4 \%$ ductility (as measured). 


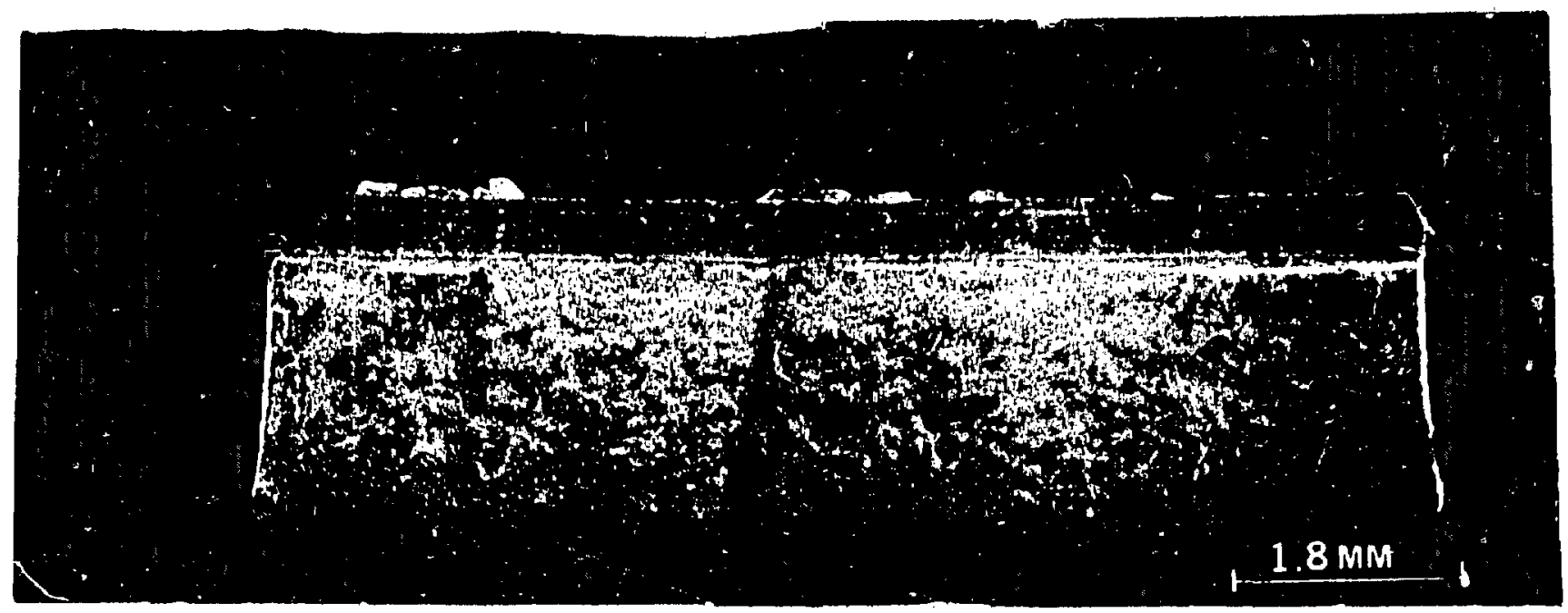

Figure 4 Fractugraph of Charpy "V" notch specimen from a 4032 alloy tested at room temperature ( 9.75 inch-1bf).

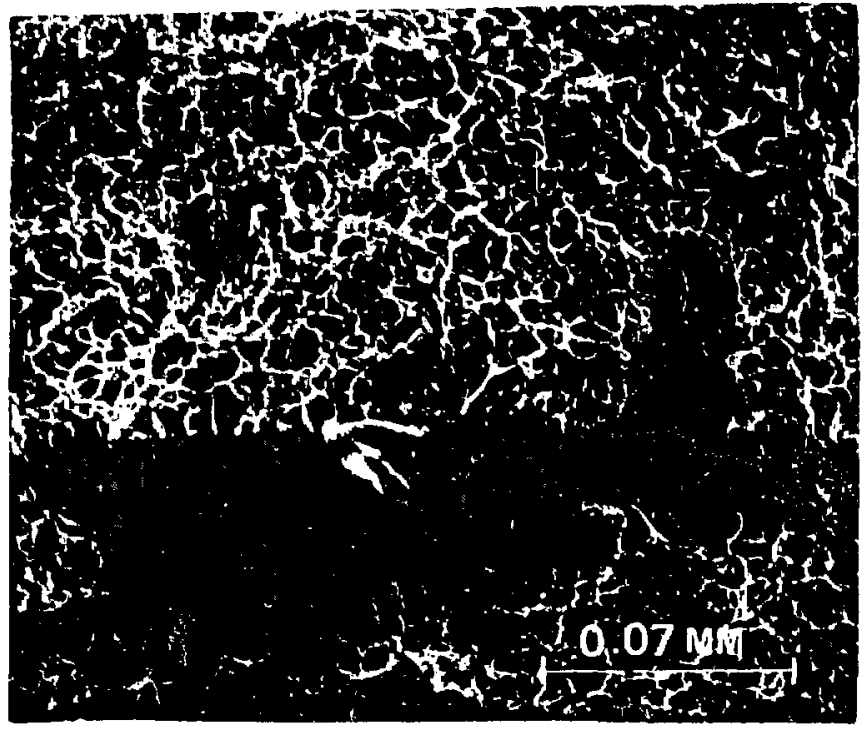

Figure $4 a$ Fractograph of area near the notch. Totally ductile fracture (typical).

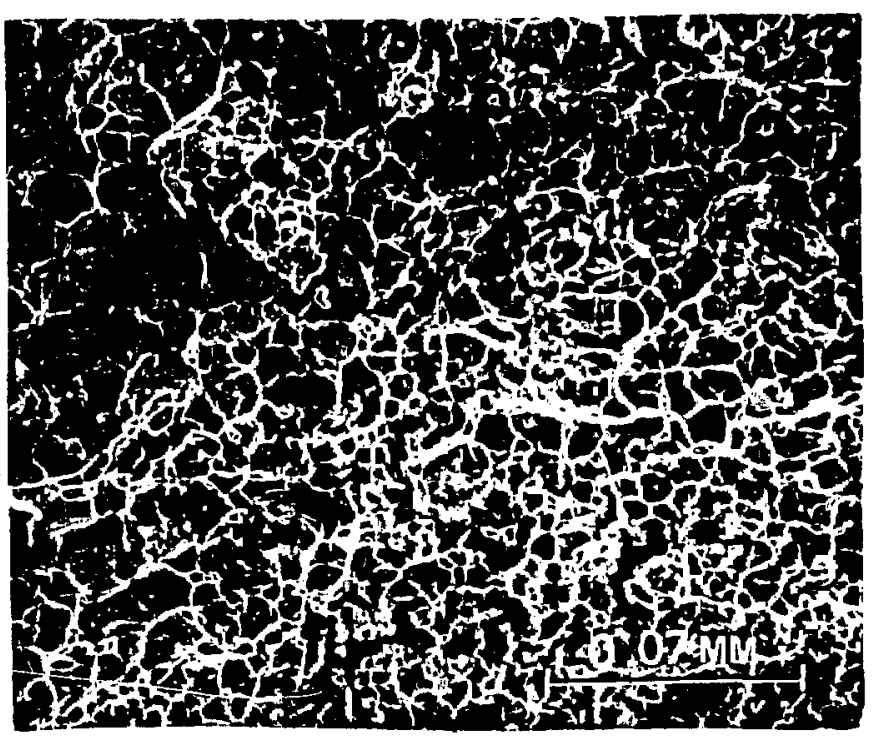

Figure $4 b$ The side opposite the notch of the specimen was also purely ductile (typical). 


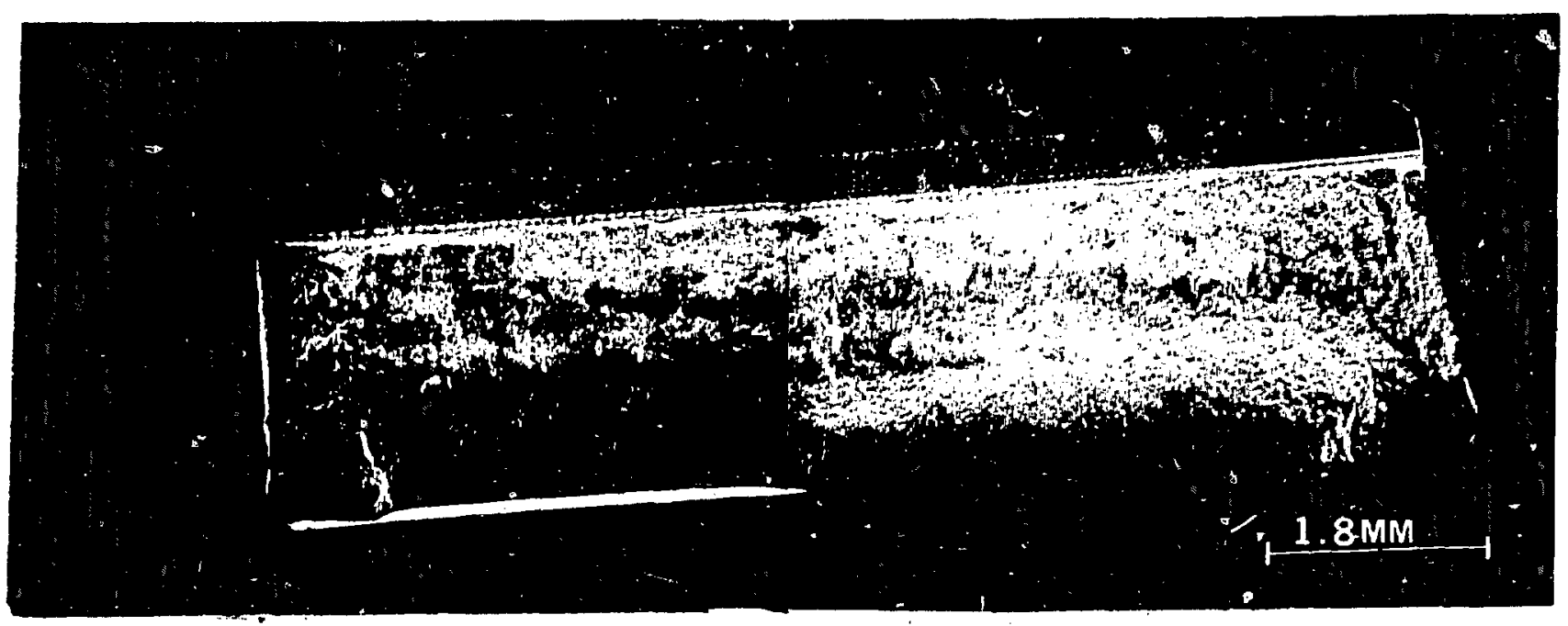

Figure 5 Fractograph of Charpy "V" notch specimen from a 4032 alloy tested ai $210^{\circ} \mathrm{F}$ (12 inch-lbf).

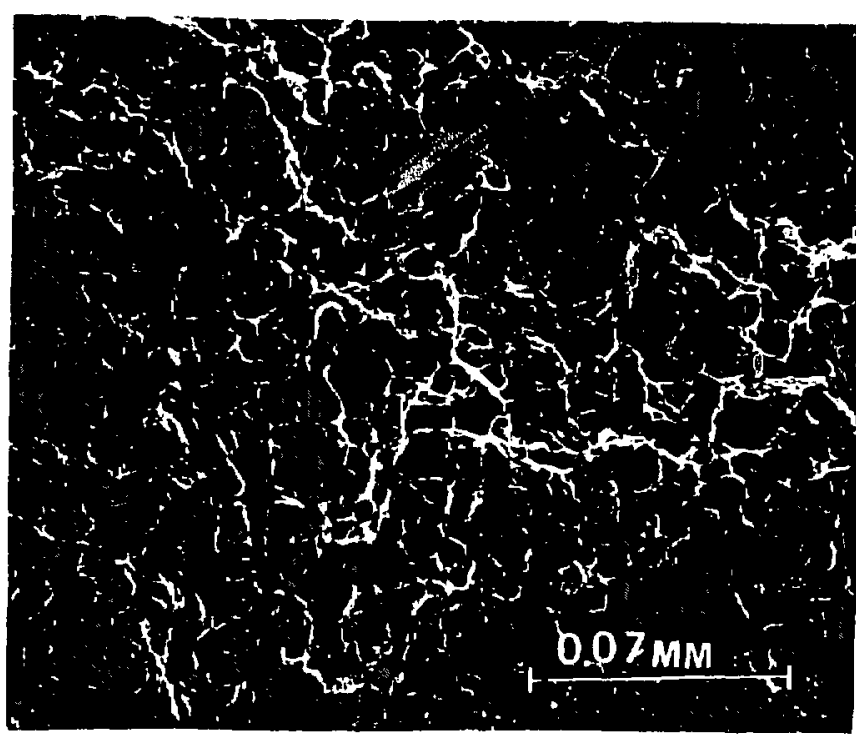

Figure 5a Essentially pure ductile failure was seen at higher magnification near the notch (typical).

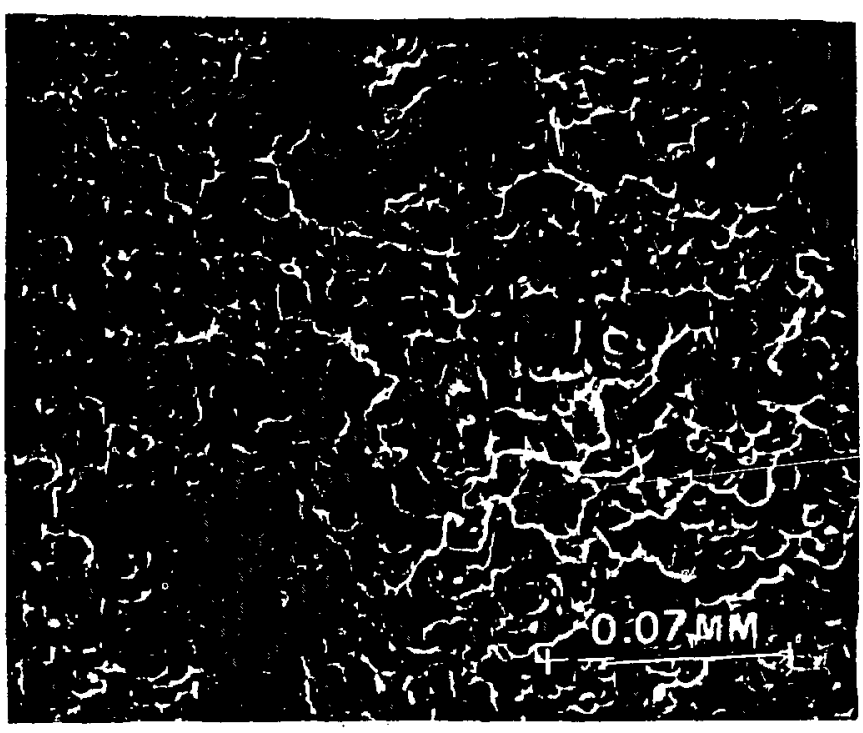

Figure $5 b$ The same mode of failure was seen on the opposite side of the fracture (typicai). 


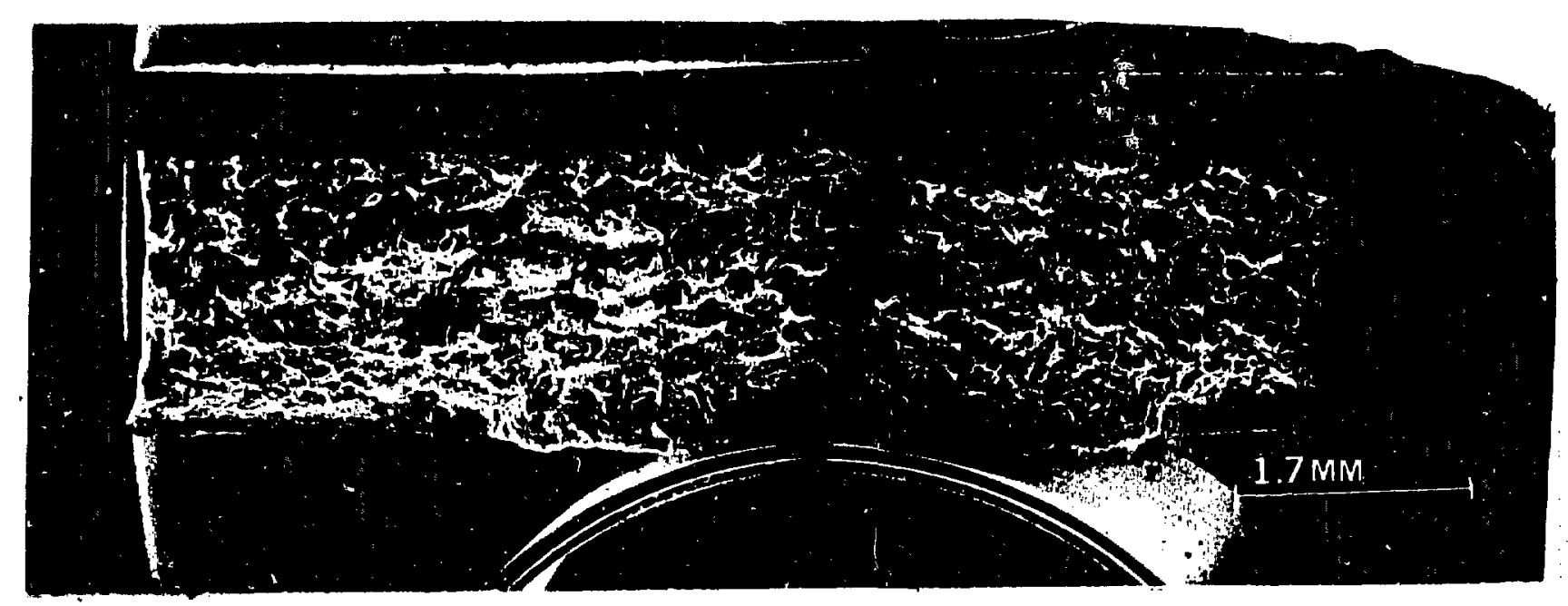

Figure 6 Low magnification SEM photograph of the fracture from a 6061 T-6 alloy impact tested at $210^{\circ} \mathrm{F}$ (18.75 inch-1bf).

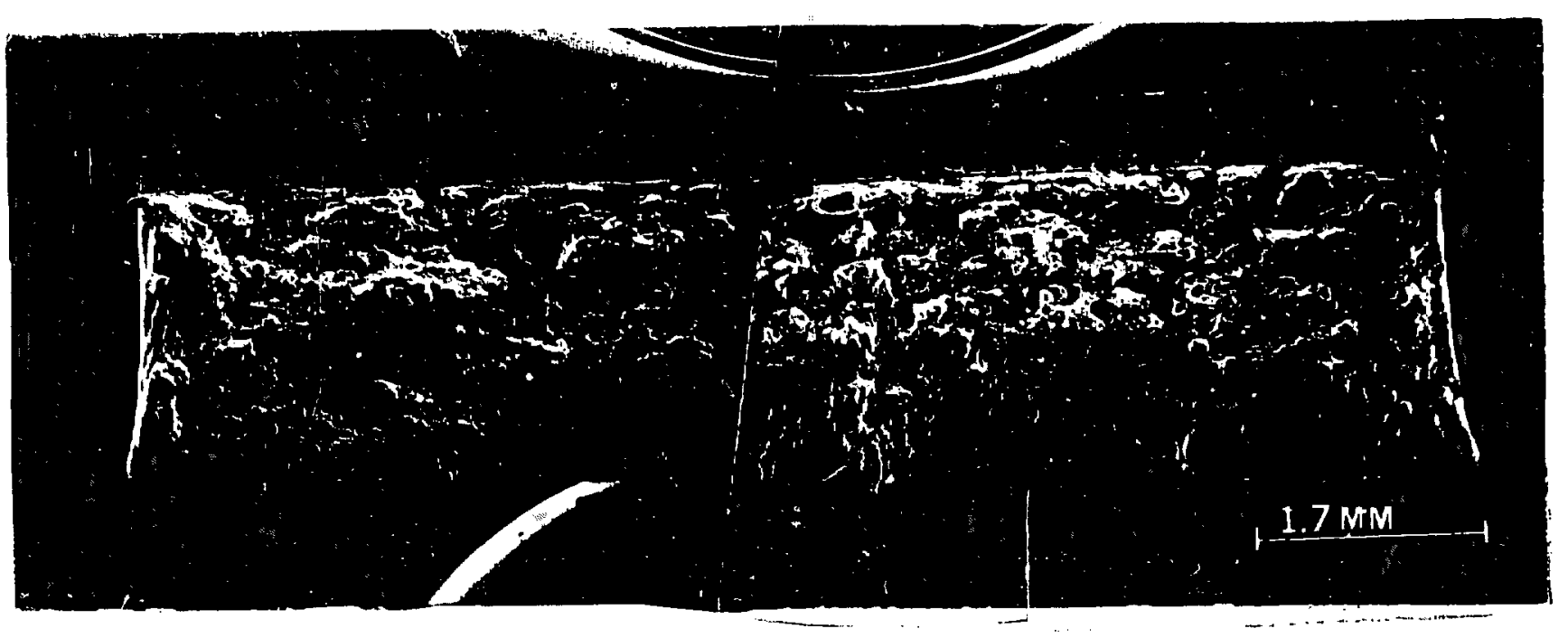

Figure 7 Fractograph of impact specimen tested at room temperature 6061 T-6 (21.75 inch-1bf). 


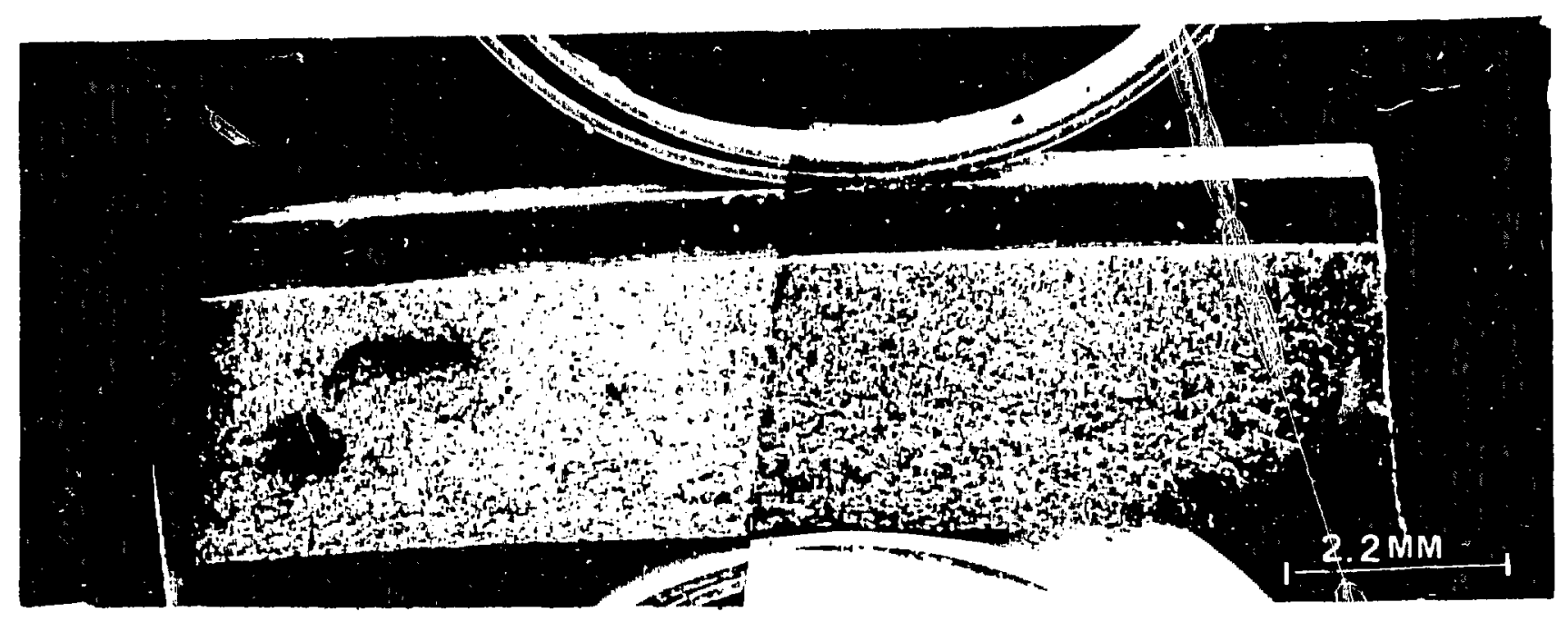

Figure 8 Low magnification SEM photograph of irradiated HFGR impact impact specimen (outside high

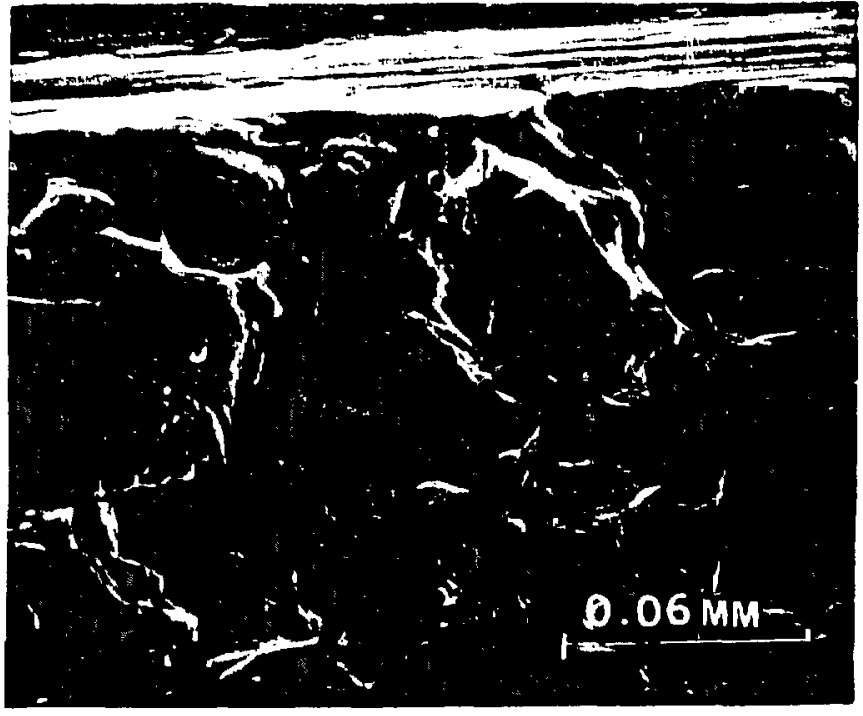

Figure $8 a$ The measured ductility area of the specimen near the notch was $8.7 \%$ (typical).

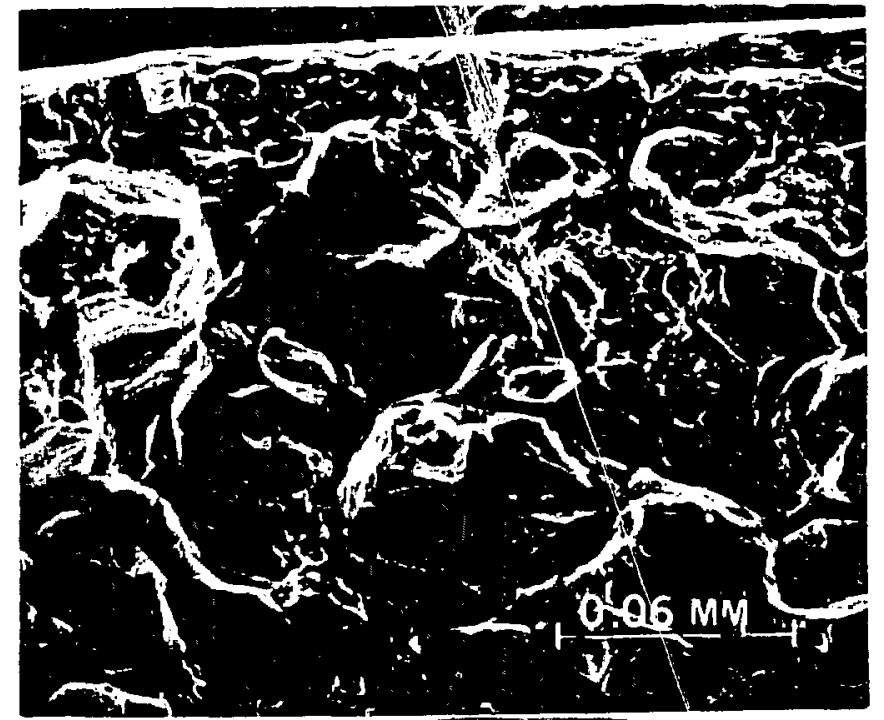

Figure $8 b$ The ductility measured on the opposite side of the specimen was $8.1 \%$ (typical). 


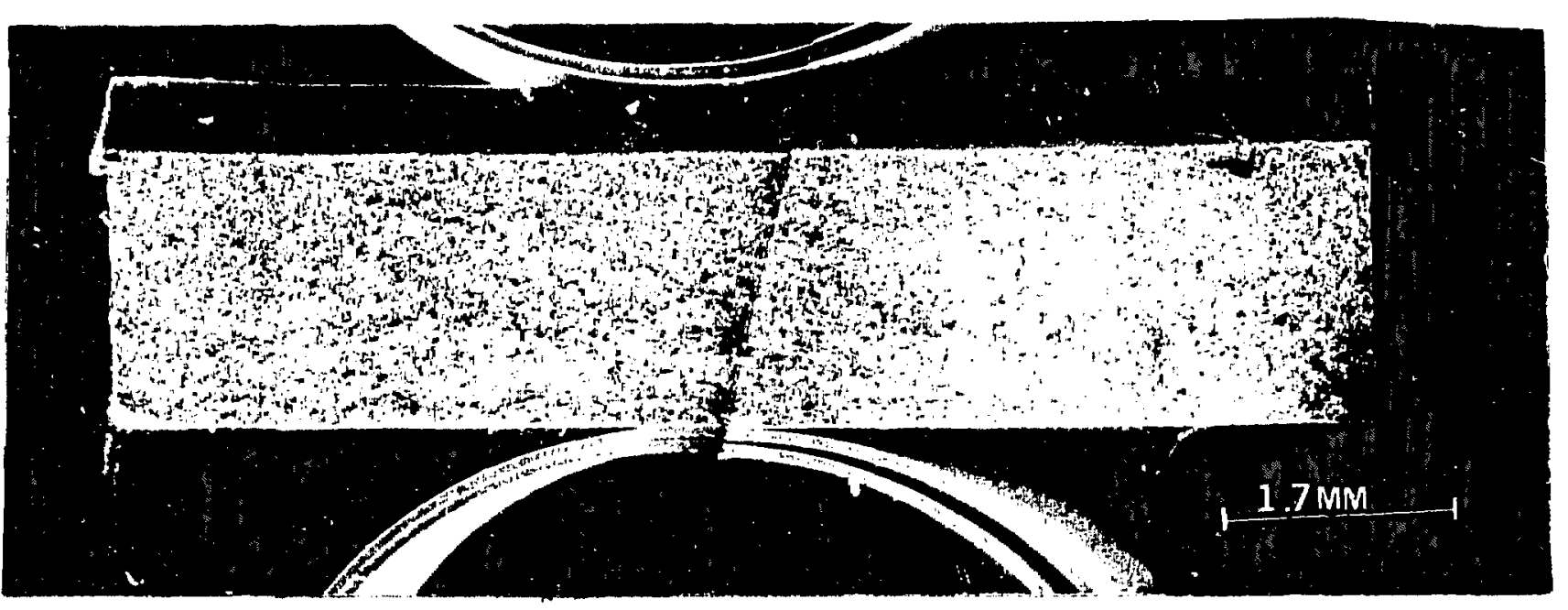

Figure 9 Fractograph of irradiated impact specimen $C-1$ (HFBR). The specimen was tested at room temperature (3.0 inch-1bf).

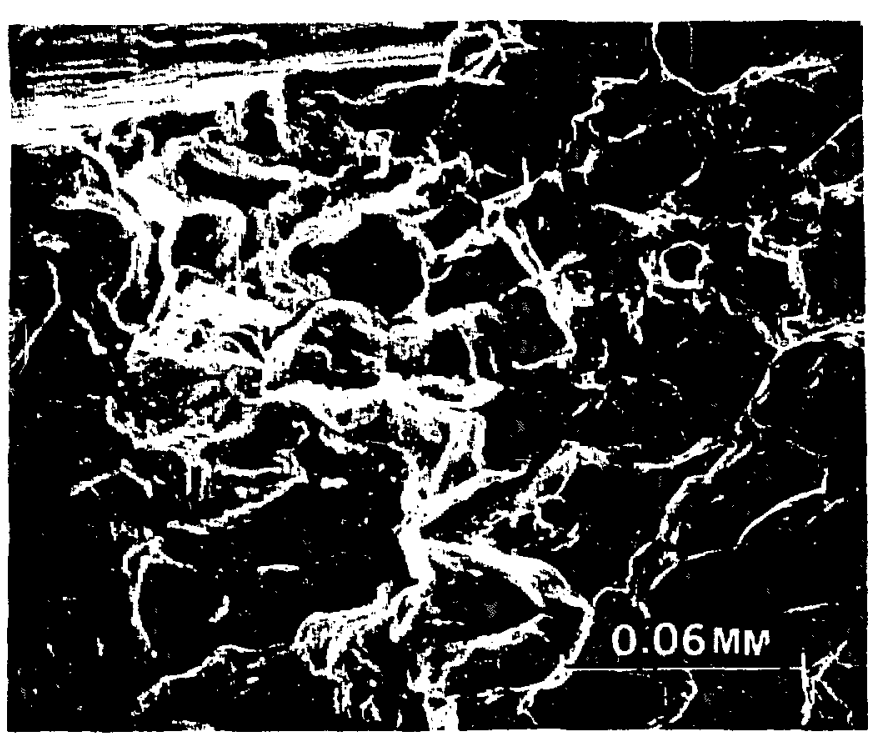

Figure 9a The ductility area measured 5.3\%(typical) near the notch.

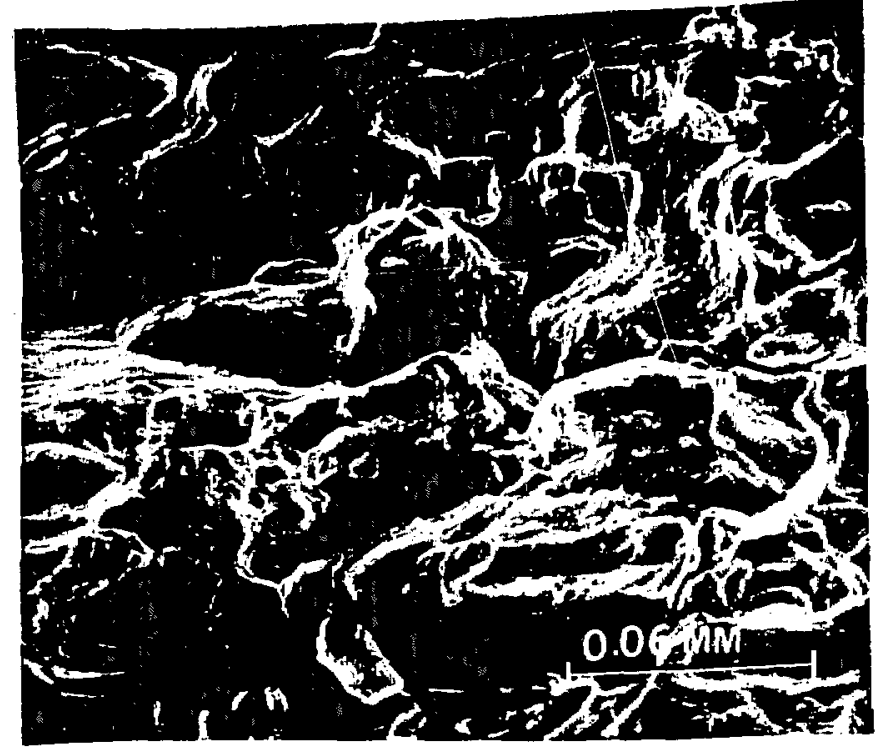

Figure 9b The opposite side of the specimen had a measured area ductility of $4.6 \%$. 


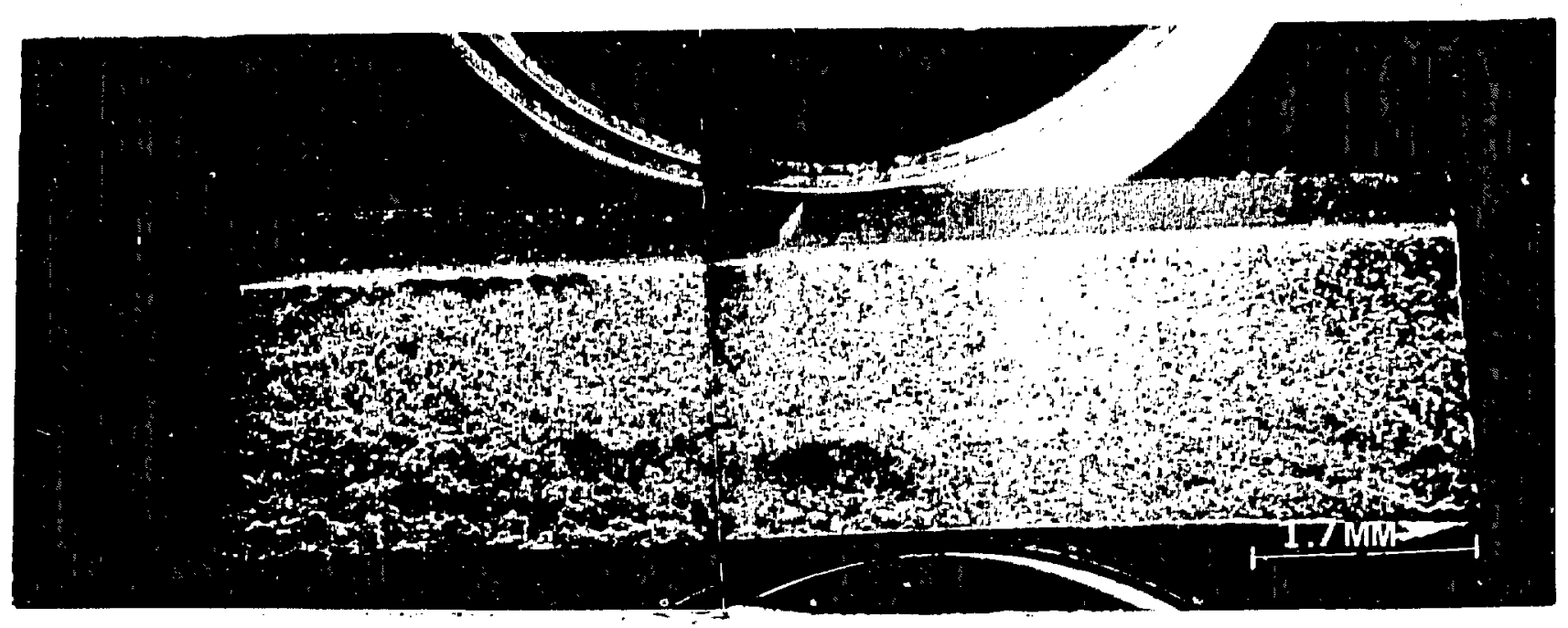

Figure 10 HFBR follower specimen (impact) $\mathrm{C}-8$ tested at room temperature (2.75 inch-ibf).

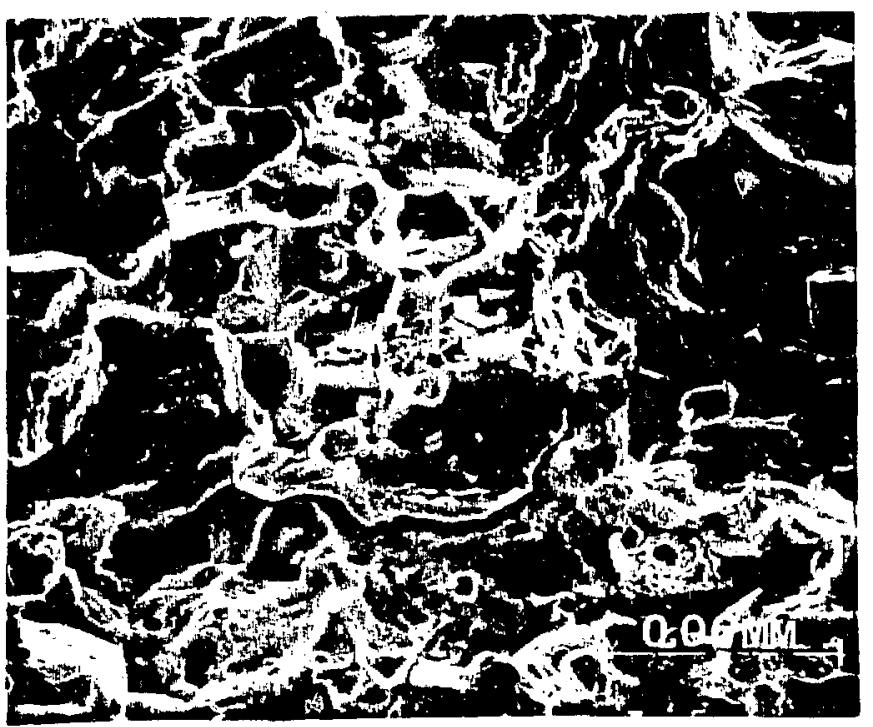

Figure 10a
The area near the notch (typical) exhibited a measured ductility area of $5.3 \%$.

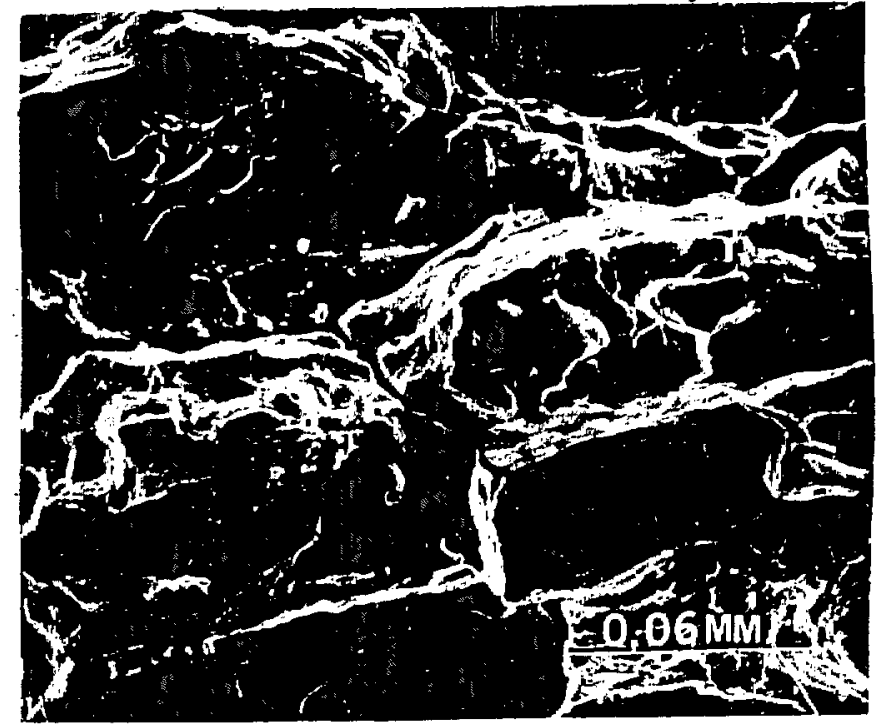

Figure 10b The opposite side of the fracture face had an area of $5.4 \%$ ductility. 


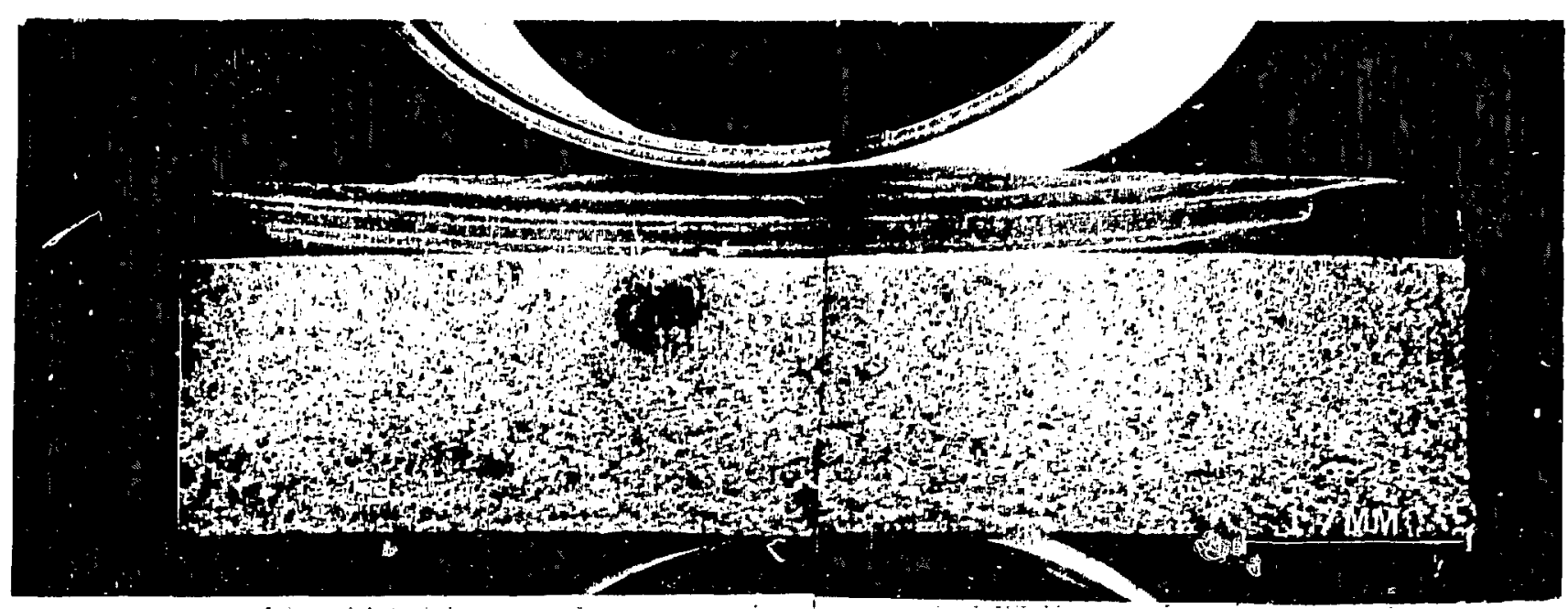

Figure 11 HFBR follower specimen (impact tested at $210^{\circ} \mathrm{F}$ ) C-4 had an absorbed impact energy of 2.0 inch-1bf.

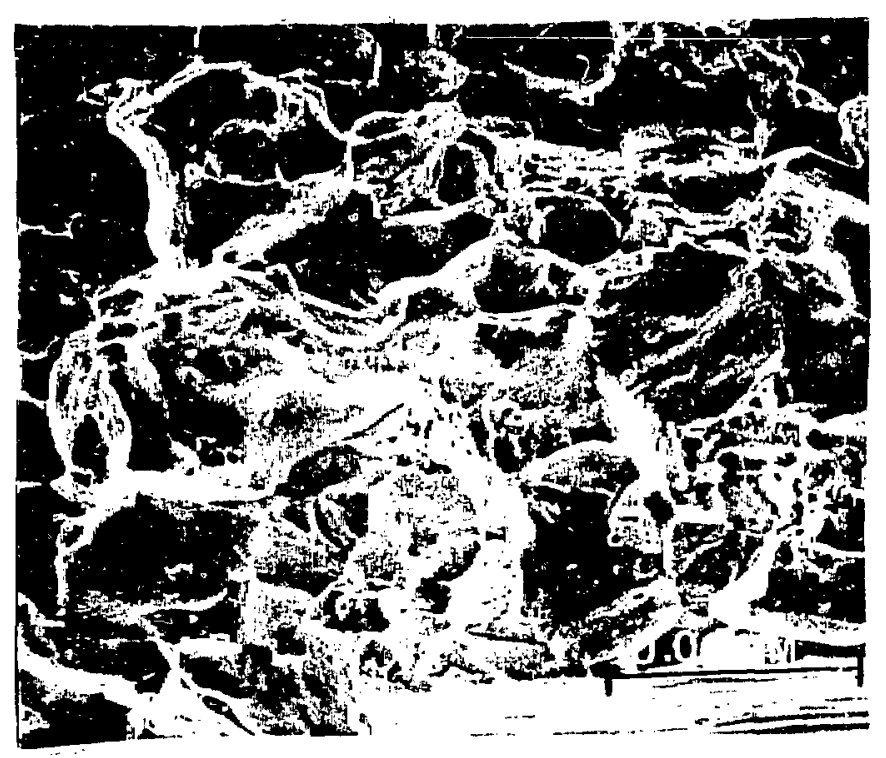

Figure 1la The fracture face of $\mathrm{C}-4$ near the notch showed a ductility area of $9.5 \%$.

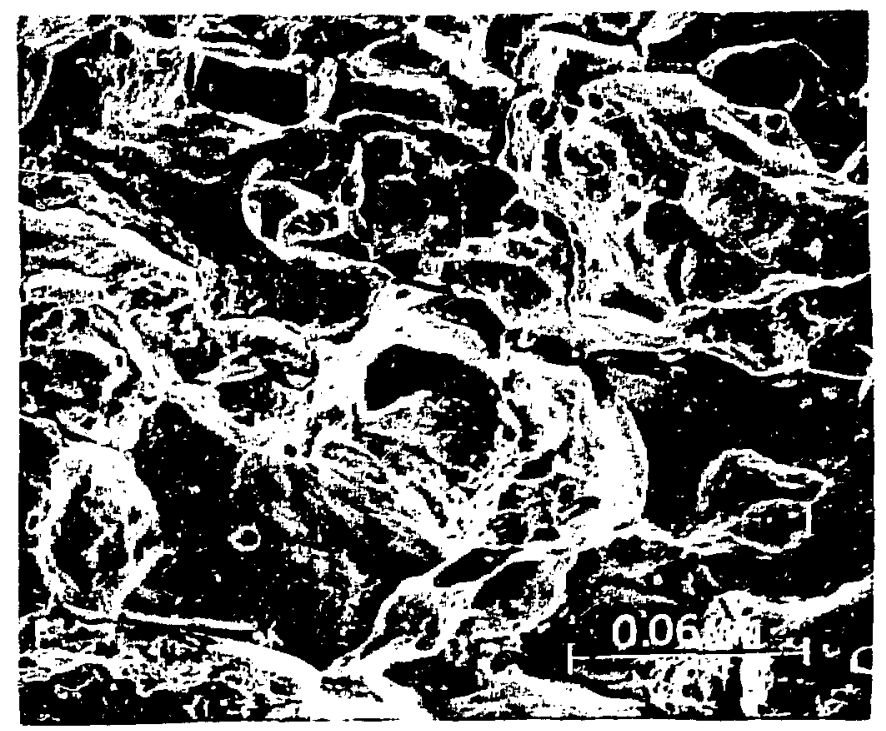

Figure 11b The ductility area on the opposite side of the fracture face measured $8.4 \%$. 


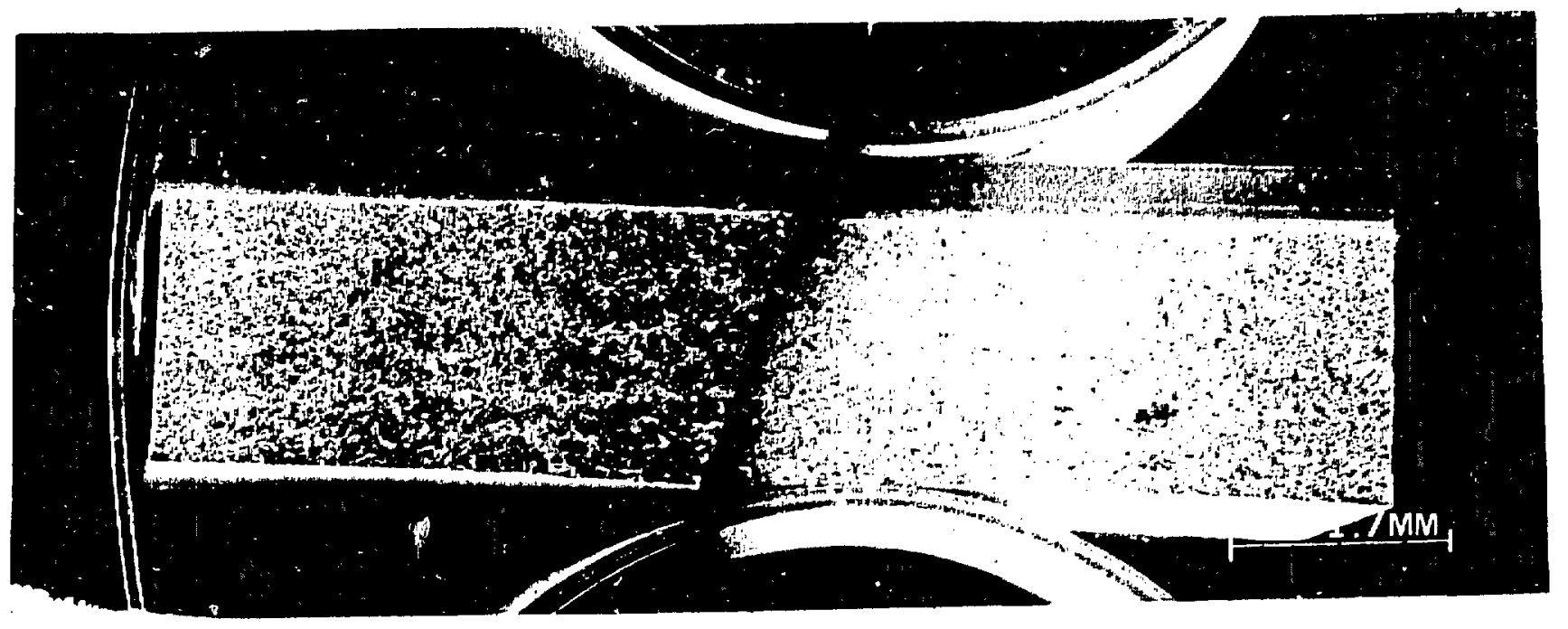

Figure 12 Another HFBR specimen $(C-5)$ impact tested at $210^{\circ} \mathrm{F}$ had an absorbed impact energy of 3.25 inch-1bf.

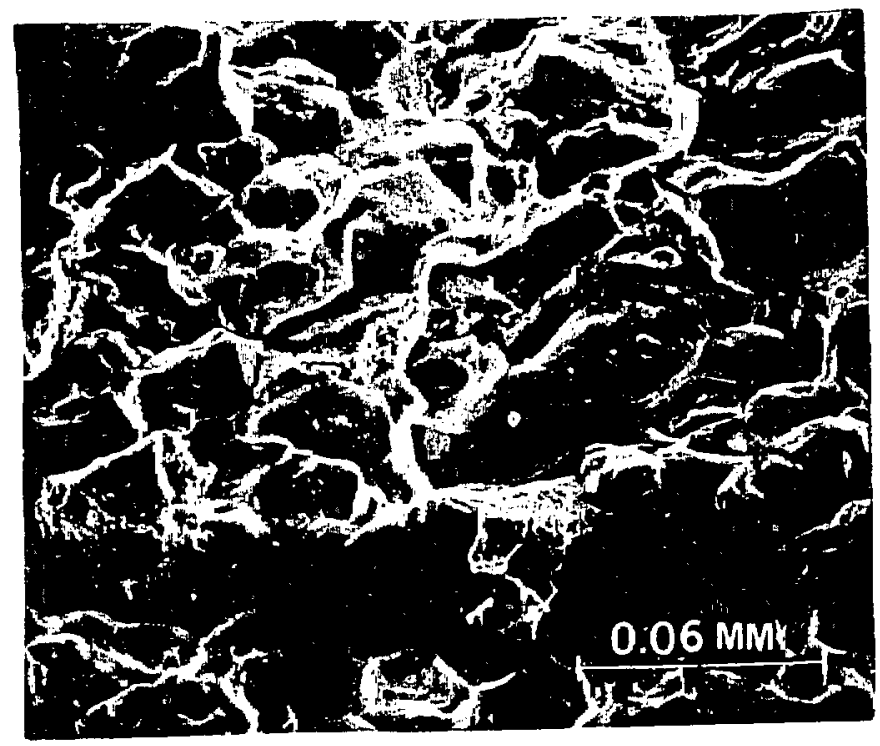

Figure $12 a$ A ductility measurement of $6.3 \%$ was cbtained near the notch.

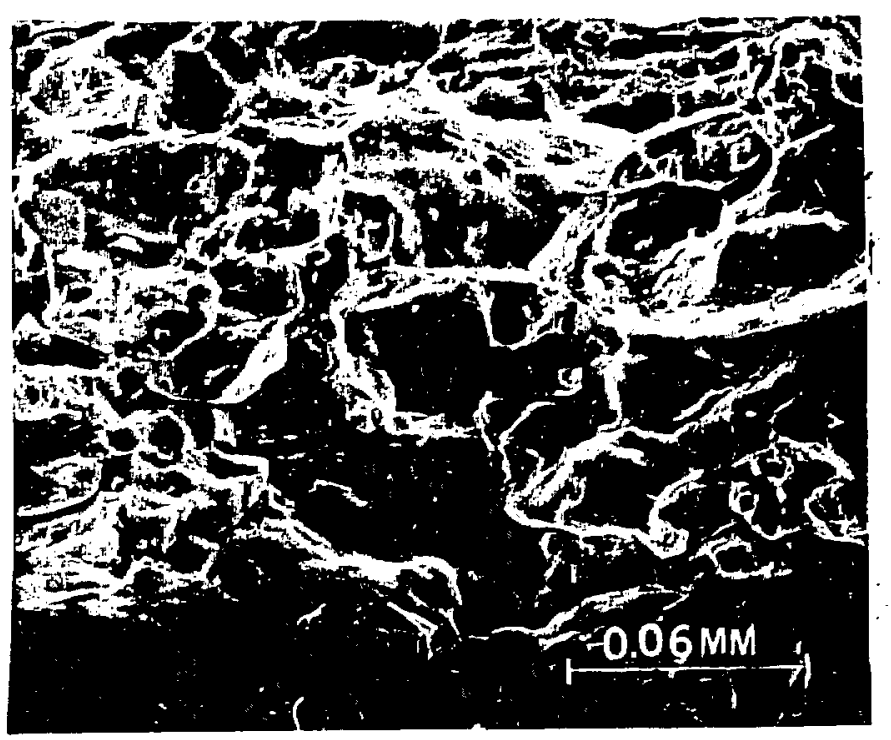

Figure 12b A ductility area of $6.8 \%$ (typical) was seen near the opposite side of the fracture. 